\title{
Pengaruh Pemberian Mikroorganisme Lokal (MOL) Rebung Bambu Surat (Gigantochloa vesticillata (Willd.) Munro) terhadap Pertumbuhan Bayam Merah (Amaranthus tricolor L.)
}

\author{
Gustomi $^{1}$, Lutfah Nurusman ${ }^{1}$, Susilo $^{1^{*}}$ \\ ${ }^{1}$ Pendidikan Biologi, Universitas Muhammadiyah Prof. Dr. Hamka. Jalan Tanah Merdeka, Pasar Rebo, Jakarta Timur 13830 \\ *Email korespondensi: susilo@uhamka.ac.id \\ doi:10.29405/j.bes/81-87121336 \\ Received: 20 Maret 2018 \\ | Accepted: 16 Mei 2018 \\ Published: Published: 05 Juni 2018

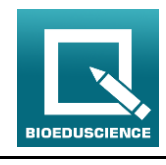

\begin{abstract}
Abstrak
Tujuan: Penelitian ini bertujuan untuk mengetahui pengaruh pemberian mikroorganisme lokal (MOL) rebung bambu terhadap pertumbuhan bayam merah (Amaranthus tricolor L.). Metode: Metode yang dipakai dalam penelitian ini adalah metode eksperimental dan desain penelitian rancangan acak lengkap (RAL) dengan 5 perlakuan dan 5 ulangan. Perlakuan tersebut adalah $\mathrm{P}_{0}$ (kontrol), $\mathrm{P}_{1}, \mathrm{P}_{2}, \mathrm{P}_{3}$, dan $\mathrm{P}_{4}$ secara berurutan perlakuan dengan MOL rebung bambu surat $5 ; 10 ; 15$; dan 20\%. Perlakuan diberikan setiap minggu dan panen tanaman bayam merah dilakukan 35 setelah pindah tanam. Data setiap parameter dilakukan uji normalitas, uji homogenitas, lalu dianalisis dengan ANAVA 1 faktor pada $\alpha=0,01$. Selanjutnya dilakukan uji BNT untuk mengetahui beda pengaruh antar perlakuan. Hasil: Pemberian MOL rebung bambu surat yang terbaik adalah perlakuan $\mathrm{P}_{2}$ dengan tinggi, berat segar, dan berat kering tanaman secara berurutan 30,34 cm; 15,40 g; dan 1,04 g. Persentase tinggi, berat segar, dan berat kering tanaman bayam merah perlakuan $\mathrm{P}_{2}$ terhadap kontrol secara berurutan 200,66; 292,22; dan 297,14\%. Kesimpulan: Pemberian MOL rebung bambu secara umum dapat meningkatkan pertumbuhan bayam merah.
\end{abstract}

Kata kunci: mikroorganisme lokal; rebung bambu: Amaranthus tricolor;

\begin{abstract}
:
Background: This study aims to determine the effect of local microorganisms (MOL) from bamboo shoots (rebung) on the growth of red spinach (Amaranthus tricolor L.). Methods: The method used in this research was experimental method and complete randomized design (RAL) design with 5 treatments and 5 replications. The treatment was P0 (control), P1, P2, P3, and P4 respectively treatment with MOL bamboo shoot bamboo 5; 10 ; 15; and 20\%. Treatment was given every week and the crop of red spinach was done 35 after planting move. The data of each parameter is done by normality test, homogeneity test, then analyzed with ANAVA 1 factor at $\alpha=$ 0,01. Furthermore, BNT test was conducted to find out the difference of influence between treatments. Results: The best application of MOL Bamboo bamboo shoots was P2 treatment with height, fresh weight, and dry weight of plant respectively $30,34 \mathrm{~cm} ; 15.40 \mathrm{~g}$; and $1.04 \mathrm{~g}$. High percentage, fresh weight, and dry weight of red spinach plant P2 treatment against control sequentially 200,66; 292.22; and 297.14\%. Conclusions: giving MOL bamboo shoots can increase the growth of red spinach.
\end{abstract}

Keywords: local microorganism; Bamboo shoots: Amaranthus tricolor;

(C) 2018 Bioeduscience. all rights reserved

\section{PENDAHULUAN}

Pola makan yang benar merupakan salah satu penentu terciptanya tubuh sehat dan segar untuk itu manusia perlu mengkonsumsi makanan yang banyak mengandung protein, mineral, vitamin $\mathrm{A}, \mathrm{B}, \mathrm{C}, \mathrm{D}$ dan lain sebagainya sehingga tubuh tidak mudah terserang oleh penyakit. Salah satu makanan tersebut adalah sayur - sayuran. Dewasa ini kebutuhan akan konsumsi makanan sehat terus mengalami peningkatan, hal ini ditandai dengan daya beli masyarakat terhadap bahan pangan organik terutama sayuran organik 
relatif cukup tinggi (Susilo \& Setyaningsih, 2018). Salah satu jenis sayuran yang dapat dikembangkan secara organik dan memiliki kandungan gizi yang baik adalah sayur bayam.

Bayam (Amaranthus sp.) merupakan tanaman berbentuk perdu yang digemari oleh masyarakat karena rasanya enak, lunak, mengandung vitamin $\mathrm{A}, \mathrm{C}$, sedikit vitamin $\mathrm{B}$, garam - garam mineral yang penting seperti kalsium, fosfor, dan zat besi (Sunarjono, 2014). Bayam yang dijual di pasaran dan biasa dikonsumsi sebagai sayuran dikenal dengan bayam cabut atau bayam sekul, yang memiliki daun serta batang warna merah mengandung pigmen berwarna merah yang bila dimasak membuat warna kuah menjadi merah (Dalimartha dan Andrian, 2013).

Meningkatnya konsumsi bayam merah oleh masyarakat menuntut para petani untuk meningkatkan produktivitas bayam merah, dan salah satu cara yang dilakukan adalah melalui pemupukan dengan pupuk anorganik (Susilo \& Suciati, 2017). Akan tetapi penggunaan pupuk anorganik semakin lama tidak efisien karena tidak sebanding dengan kenaikan hasil panen. Harga pupuk anorganik yang tinggi menyebabkan para petani kesulitan untuk mendapatkan pupuk tersebut. Selain itu residu dari pupuk anorganik juga berdampak negatif pada lingkungan. Mulyono (2014) mengatakan bahwa pupuk anorganik lebih mudah menguap dan tidak memiliki kemampuan memperbaiki kondisi lahan sehingga residu yang dihasilkan akan merusak mikroorganisme tanah.

Untuk mengurangi residu yang dihasilkan dari pupuk anorganik maka diperlukan pengganti pupuk anorganik berupa pupuk organik. Pupuk organik merupakan pupuk yang berasal dari bahan - bahan hidup atau mahkluk hidup yang sudah mati, meliputi kotoran hewan, serasah, sampah, dan berbagai produk dari organisme hidup (Samekto, 2006). Penggunaan pupuk organik dalam bercocok tanam bisa menjadi pilihan yang tepat bagi para petani untuk mendapatkan hasil panen yang lebih baik, karena tanaman yang diberi pupuk organik memiliki daya tahan terhadap serangan hama ataupun penyakit (Erwin, 2017). Sedangkan dari sisi ekonomi penggunaan pupuk organik dapat menekan biaya pengeluaran, sehingga para petani akan mendapatkan keuntungan yang lebih banyak lagi.

Berbagai macam bahan organik dapat digunakan dalam pembuatan pupuk organik, salah satunya adalah rebung bambu. Rebung bambu di perdesaan populasinya cukup besar, akan tetapi kurang bisa dimanfaatkan secara maksimal oleh masyarakat desa. Bagi masyarakat desa rebung bambu umumnya hanya dikonsumsi sebagai sayur atau untuk isi lumpia. Padahal lebih dari itu rebung bambu mengandung unsur hara penting yang dapat meningkatkan pertumbuhan serta perkembangan tanaman. Rebung bambu mengandung unsur kalium 533 $\mathrm{mg}$, fosfor $59 \mathrm{mg}$, dan kalsium $13 \mathrm{mg}$, serta diduga juga mengandung fitohormon berupa gibrelin (Nugroho, 2014). Anggorowati dan Hardiyati (2010) mengatakan bahwa fitohormon merupakan bahan organik yang dapat disintesis oleh tanaman dengan konsentrasi rendah, dan mampu menimbulkan tanggapan fisiologis serta morfologis. Sehingga diharapkan dengan adanya mikroorganisme lokal rebung bambu sebagai pupuk organik dapat meningkatkan produktivitas bayam merah, menambah penghasilan para petani, serta bisa membuka peluang terwujudnya pertanian secara organik.

\section{MATERI DAN METODE}

Penelitian ini menggunakan desain rancangan acak lengkap dengan 5 perlakuan dan 5 ulangan. Perlakuan tersebut $\mathrm{P}_{0}$ (kontrol), $\mathrm{P}_{1}, \mathrm{P}_{2}$, $\mathrm{P}_{3}$, dan $\mathrm{P}_{4}$ secara berurutan adalah perlakuan dengan MOL rebung bambu surat 5; 10; 15; dan 20

Tahap awal penelitian ini dimulai dengan membuat MOL rebung bambu surat dengan cara mencampur 500 gram rebung bambu, 1 liter air leri beras, dan 0,25 ons gula merah halus. Selanjutnya blender campuran tersebut dan masukkan ke dalam toples. Setelah itu tutup dengan plastik trasparan dan hubungkan toples 
yang berisi bahan - bahan MOL dengan selang plastik ke botol air mineral $600 \mathrm{ml}$ berisi air untuk menjaga tekanan mikroorganisme lokal (MOL) rebung bambu, dan mencegah udara agar tidak masuk. MOL tersebut difermentasi selama 15 hari.

Tanaman bayam merah diaklimatisasi selama 1 minggu. Hari ke tujuh setelah pindah tanam ke polybag, mikroorganisme lokal (MOL) rebung bambusurat diaplikasikan ke tanaman bayam merah setiap seminggu sekali. Pemberian mikroorganisme lokalrebung bambu surat dilakukan pada sore hari. Pengambilan data parameter yang meliputi tinggi, berat segar, dan berat kering tanaman dilakukan pada 35 hari setelah pindah tanam. Analisis data dalam penelitian ini dengan menggunakan ANAVA 1 faktor pada $\alpha=0,01$ yang dilanjutkan uji BNT untuk mengetahui beda pengaruh antar perlakuan (Nurgana, 1985).

\section{HASIL}

Hasil penelitian dari pengaruh pemberian mikroorganisme lokal (MOL) rebung bambu surat (Gigantochloa vesticillata (Willd.) Munro) terhadap parameter pertumbuhan (tinggi, berat segar, dan berat kering) tanaman bayam merah tercantum pada tabel 1 .

Tabel 1. Hasil rata - rata tinggi, berat segar, dan berat kering tanaman bayam merah umur 35 HSPT

\begin{tabular}{cccc}
\hline Perlakuan & $\begin{array}{c}\text { Tinggi } \\
\text { tanaman } \\
(\mathrm{cm})\end{array}$ & $\begin{array}{c}\text { Berat segar } \\
(\mathrm{g})\end{array}$ & $\begin{array}{c}\text { Berat } \\
\text { kering } \\
(\mathrm{g})\end{array}$ \\
\hline $0 \%$ & $15,12^{\mathrm{a}}$ & $2,27^{\mathrm{a}}$ & $0,35^{\mathrm{a}}$ \\
$5 \%$ & $22,84^{\mathrm{b}}$ & $11,45^{\mathrm{b}}$ & $0,79^{\mathrm{b}}$ \\
$10 \%$ & $30,34^{\mathrm{c}}$ & $15,40^{\mathrm{c}}$ & $1,04^{\mathrm{c}}$ \\
$15 \%$ & $19,9^{\mathrm{bd}}$ & $7,95^{\mathrm{a}}$ & $0,58^{\mathrm{a}}$ \\
$20 \%$ & $19,08^{\mathrm{d}}$ & $7,18^{\mathrm{a}}$ & $0,55^{\mathrm{a}}$ \\
\hline
\end{tabular}

Keterangan: Angka yang diikuti huruf superskrip yang sama, menunjukkan tidak ada perbedaan yang signifikan

Dari data yang ditunjukkan tabel 1 terlihat bahwa respon yang diberikan tanaman bayam merah terhadap pemberian MOL rebung bambu surat sangat beragam. Hal ini ditandai dengan tanaman bayam merah memiliki tinggi yang bervariasi untuk setiap perlakuan.
Berdasarkan data yang disajikan pada tabel 1 dan gambar 1 rata - rata tinggi tanaman bayam merah paling rendah ditunjukkan oleh tanaman kontrol dengan nilai $15,12 \mathrm{~cm}$. Setelah itu terjadi peningkatan rata - rata tinggi tanaman bayam merah pada perlakuan 5 dan $10 \%$ masing masing sebesar 22,84 dan $30,34 \mathrm{~cm}$. Perlakuan 15 dan $20 \%$ memiliki rata - rata tinggi tanaman lebih rendah dibandingkan perlakuan 5 dan 10\%. Akan tetapi memiliki rata - rata tinggi lebih baik dibandingkan tanaman kontrol dengan nilai masing - masing 19,9dan 19,08 cm.

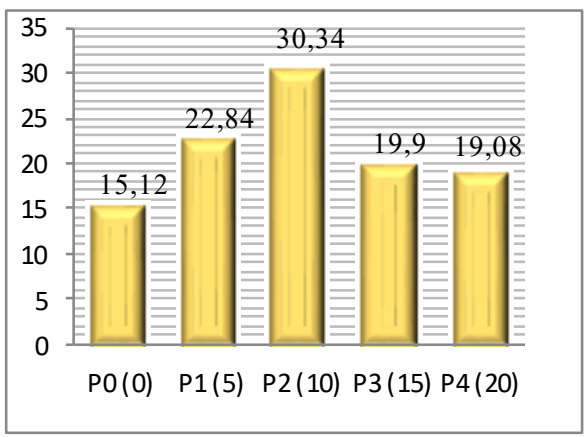

Gambar 1. rata- rata tinggitanaman bayam merah 35 HSPT pada berbagai konsentrasi MOL rebung bambu surat.

Dibawah ini adalah contoh diagram batang serta tata letak judul diagram, keterangan serta penyajiannya. Apabila area paragraph tidak muat maka gambar langsung di letakkan di halaman berikutnya.

Hasil uji distribusi normalitas menunjukkan bahwa data tinggi tanaman bayam merah berdistribusi normal. Hasil uji homogenitas Barlett bahwa data tinggi tanaman bayam merah yang diamati bervariansi homogen. Uji ANAVA 1 faktor menunjukkan bahwa pemberian MOL rebung bambu surat berpengaruh terhadap tinggi tanaman bayam merah.

Berdasarkan data berat segar tanaman bayam merah yang disajikan pada tabel 1 dan gambar 2 menunjukkan bahwa rata - rata berat segar tanaman bayam merah paling rendah adalah tanaman kontrol sebesar 5,27 gram. Rata rata berat segar tertinggi pada perlakuan $10 \%$ sebesar 15,40 gram. Sedangkan nilai rata - rata 
berat segar pada perlakuan $5 ; 15$; dan $20 \%$ secara berturut - turut 11,$45 ; 7,9$; dan 7,18 gram.

Uji distribusi normalitas data berat segar tanaman bayam merah berdistribusi normal. Uji homogenitas Barlett terhadap berat segar tanaman bayam merah menunjukkan bahwa berat segar tanaman bayam merah bervariansi homogen. Hasil uji ANAVA 1 faktor menunjukkan bahwa perlakuan dengan MOL rebung bambu surat berpengaruh terhadap berat segar tanaman bayam merah.

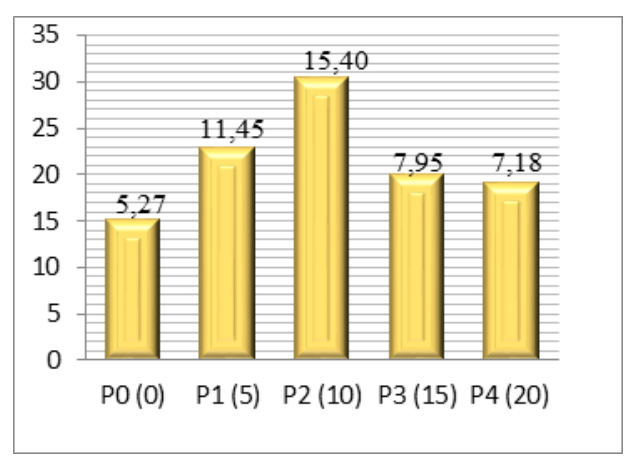

Gambar 2. Rata- rata berat segar tanaman bayam merah 35 HSPT pada berbagai konsentrasi MOL rebung bambu surat.

Hasil uji BNT menjelaskan bahwa pengaruh perlakuan $\mathrm{P}_{1}, \mathrm{P}_{2}$, sangat berbeda nyata terhadap pengaruh perlakuan $\mathrm{P}_{0}$. Pengaruh perlakuan $\mathrm{P}_{3}, \mathrm{P}_{4}$ sangat berbeda nyata terhadap $\mathrm{P}_{2}$. Pada pengaruh perlakuan $\mathrm{P}_{2}, \mathrm{P}_{3}$ dan $\mathrm{P}_{4}$ berbeda nyata terhadap perlakuan $\mathrm{P}_{1}$. Pada pengaruh perlakuan $\mathrm{P}_{3}$ dan $\mathrm{P}_{4}$ tidak berbeda nyata terhadap perlakuan $\mathrm{P}_{0}$, dan pengaruh perlakuan $\mathrm{P}_{3}$ tidak berbeda nyata terhadap perlakuan $\mathrm{P}_{4}$. Persentase berat segar tanaman bayam merah perlakuan $5 ; 10 ; 15$; dan $20 \%$ MOL rebung bambu surat terhadap tanaman kontrol secara berturut - turut adalah 217,$27 ; 292,22 ; 150,85$; dan $136,24 \%$.

Data yang disajikan pada tabel 1 dan gambar 3 menunjukkan bahwa tanaman bayam merah memiliki berat kering yang bervariasi setelah diberi perlakuan MOL rebung bambu surat. Terlihat bahwa perlakuan dengan MOL rebung bambu surat perlakuan $10 \%$ memiliki rata - rata berat kering 1,04 gram lebih tinggi dibandingkan rata - rata berat kering tanaman kontrol yang hanya 0,35 gram.

Hasil uji distribusi normalitas terhadap berat kering tanaman bayam merah menunjukkan bahwa data berat kering tanaman bayam merah terdistribusi normal. Uji homogenitas Barlett menunjukkan bahwa berat kering tanaman bayam merah bervariansi homogen. Hasil uji ANAVA 1 faktor menunjukkan bahwa pemberian MOL rebung bambu surat berpengaruh terhadap berat kering tanaman bayam merah.

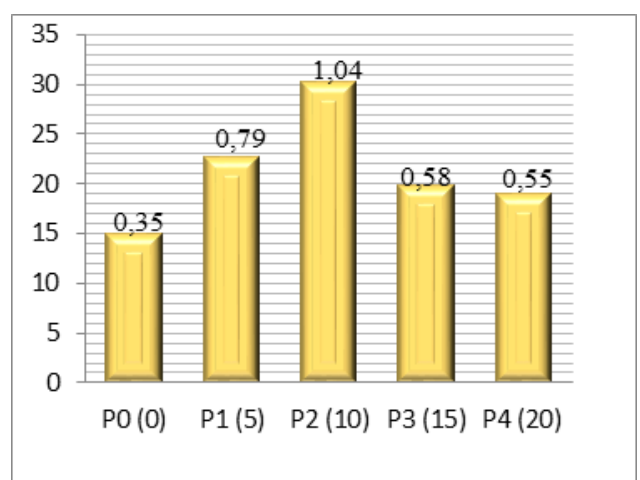

Gambar 3. Rata- rata berat kering tanaman bayam merah 35 HSPT pada berbagai konsentrasi MOL rebung bambu surat

Hasil uji BNT memperlihatkan bahwa pengaruh perlakuan $\mathrm{P}_{1}, \mathrm{P}_{2}$, berbeda sangat nyata terhadap perlakuan $\mathrm{P}_{0}$. Pada Perlakuan $\mathrm{P}_{3}$ dan $\mathrm{P}_{4}$ berbeda sangat nyata dengan perlakuan $\mathrm{P}_{2}$. Pengaruh perlakuan $\mathrm{P}_{3}$ berbeda nyata dengan $\mathrm{P}_{0}$. Sedangkan pengaruh perlakuan $\mathrm{P}_{4}$ dan $\mathrm{P}_{2}$ berbeda nyata dengan $\mathrm{P}_{1}$. Perlakuan $\mathrm{P}_{4}$ memperlihatkan bahwa tidak berbeda nyata dengan perlakuan $\mathrm{P}_{0}$. Pengaruh perlakuan $\mathrm{P}_{3}$ tidak berbeda nyata terhadap perlakuan $\mathrm{P}_{1}$, dan pengaruh perlakuan $\mathrm{P}_{3}$ tidak berbeda terhadap perlakuan $\mathrm{P}_{4}$ Persentase peningkatan berat kering tanaman perlakuan 5; 10; 15; dan $20 \%$ MOL rebung bambu surat terhadap tanaman kontrol secara berurutan 225,$71 ; 297,14 ; 165,71$; dan $157,14 \%$.

\section{PEMBAHASAN}

Tanaman kontrol memiliki tinggi, berat segar, dan berat kering yang paling rendah dibandingkan tanaman dengan perlakuan MOL rebung bambu surat. Hal ini mungkinasupan nutrisi yang diperlukan untuk pertumbuhan 
tanaman bayam merah tidak mencukupi, karena unsur hara yang didapat hanya dari media tanam saja dan jumlahnya masih kurang.

Tinggi tanaman bayam merah perlakuan $10 \%$ memberikan hasil terbaik. Hal ini mungkin karena jumlah keseimbangan hara esensial perlakuan $10 \%$ adalah yang terbaik untuk mendorong pertumbuhan tanaman bayam merah. Unsur hara esensial memang dibutuhkan untuk pertumbuhan tanaman karena pada umumnya unsur hara ini berasal dari tanah. Menurut Lakitan (2010), tumbuhan tidak akan bisa melengkapi daur hidupnya sampai menghasilkan biji yang dapat tumbuh bila unsur hara esensial tersebut belum terpenuhi.

Keseimbangan hara perlakuan $10 \%$ adalah yang terbaik untuk mendorong kerja hormon gibrelin. Gibrelin mempengaruhi panjang batang, dan pada batang muda hormon ini dapat meningkatkan panjang ruas tanpa mempengaruhi jumlah ruas ( Heddy, 1986).Sejalan dengan pendapat Lakitan (2010) tumbuhan menghasilkan vitamin untuk kepentingan tumbuhan itu sendiri dan hormon - hormon yang merupakan sarana bagi tumbuhan untuk berkomunikasi dengan organnya dalam mengendalikan dan mengkoordinasi pertumbuhan serta perkembangan tanaman.

Berat segar tanaman bayam merah perlakuan $10 \%$ memberikan hasil terbaik. Hal ini mungkin karena proses difusi akar terhadap unsur hara dalam tanah sudah berlangsung dengan baik. Sehingga ion - ion organik yang larut dalam air dapat terakumulasi serta dapat ditranslokasikan ke seluruh organ tumbuhan secara maksimal dan fosfor adalah salah satunya. Menurut Samekto (2006) fosfor mudah ditraslokasikan ke seluruh organ tanaman yang nantinya akan membantu proses pertumbuhan tanaman dan pengikatan energi.

Selain itu juga mungkin karena pada perlakuan $10 \%$ memiliki diameter batang dan ukuran daun yang lebih besar. Sehingga memberikan kontribusi untuk menambah berat segar tanaman bayam merah. Perlakuan 10\% memberikan hasil terbaik untuk berat kering.
Mungkin hal ini dikarenakan keseimbangan unsur hara dalam MOL rebung menjadikan proses metabolisme menjadi lebih baik, dan mungkin juga karena adanya hormon gibrelin yang tersebar dalam jaringan tumbuhan.Peranan zat - zat tumbuh penting dalam koordinasi perkembangan tumbuhan karena mereka mudah bergerak dalam jaringan xylem dan floem (Heddy,1986).

Meskipun perlakuan $5 \%$ sudah mendapatkan tambahan nutrisi dari MOL rebung bambu surat ternyata masih belum cukup untuk meningkatkan tinggi tanaman bayam merah, dan dengan demikian akan menyebabkan pertumbuhan tanaman bayam merah menjadi kurang optimal. Sesuai pendapat Lakitan (2010) bahwa apabila unsur hara kurang tersedia pada media tanam tentu pertumbuhan tanaman akan terhambat.

Selain itu mungkin juga karena jumlah mikroba dalam MOL rebung bambu surat belum mencukupi untuk melakukan perombakan jasad renik yang ada di dalam media tanam. Mikroba berperan sebagai dekomposer untuk mempercepat lapuknya bahan organik serta menjadi antagonis untuk patogen (Redaksi Trubus, 2013).

Berat segar perlakuan 5\% lebih baik daripada kontrol. Kemungkinan karena kalsium yang diserap oleh tanaman bayam merah dalam bentuk kation yang nantinya akan bekerja sama dengan mikroba untuk mengikat nitrogen dalam tanah. Kalsium berguna untuk menguatkan dinding sel (lamela tengah), pembelahan sel - sel meristematik, dan membantu dalam pengambilan nitrat (Dwidjoseputro, 1978).

Nutrisi tambahan yang diberikan ke tanaman bayam merah berbentuk cairan. Pemberian unsur hara berupa cairan ini mungkin dapat meningkatkan daya serap air dan unsur hara oleh organ tanaman yang nantinya akan berpengaruh dalam proses transpirasi. Menurut Yudiarti (2008) pergerakan air dari akar ke bagian atas tanaman lewat xylem adalah hasil tarikan dari proses penguapan air dari permukaan daun lewat stomata, sehingga dengan demikian 
tanaman banyak kehilangan air dan jaringanpun akan kehilangan sistem turgor.

Dwijoseputro (1978) mengatakan bahwa faktor internal yang mempengaruhi laju transpirasi tanaman antara lain besar kecilnya daun, tebal tipisnya daun, bentuk stomata, lokasi stomata, dan ukuran stomata. Perlakuan 15 dan $20 \%$ memiliki tinggi tanaman lebih rendah dibandingkan perlakuan $10 \%$. Hal ini mungkin karena unsur hara tambahan yang diberikan pada perlakuan 15 dan $20 \%$ jumlahnya melebihi kebutuhan tanaman bayam merah dalam pertumbuhannya. Sehinggapertumbuhan tanaman bayam merah terhambat dan mengalami penurunan. Selain itu juga mugkin karena unsur hara yang diberikan secara berlebihan malah akan menjadi toksin.

Lakitan (2010) mengatakan bahwa unsur hara yang diberikan ke tanaman terlalu banyak akan menyebabkan keracunan. Selain itu juga mungkin karena MOL rebung bambu surat kurang efektif untuk dijadikan pupuk hayati dalam konsentrasi tinggi. Mulyono (2014) mengatakan bahwa mikroorganisme lokal dapat dijadikan sebagai pupuk langsung, bahan starter, dan pengomposan bahan organik asalkan dengan konsentrasi yang rendah.

Mungkin juga karena MOL dengan konsentrasi tinggi akan menyebabkan derajat keasaman tanah menjadi lebih asam. Keadaan seperti ini akan meyebabkan pertumbuhan akar tanaman bayam merah kurang optimal. Akibatnya proses penyerapan dan distribusi unsur hara ke organ tanaman tidak akan berjalan secara optimal (Andrianni et al., 2017). Cara aplikasi MOL rebung bambu harus diencerkan terlebih dahulu karena bila tidak diencerkan akan mengakibatkan akar terbakar, dan tanaman menjadi mati (Setiawan, 2010).

Berat segar dan berat kering perlakuan 15 dan 20\% tidak berbeda nyata. Mungkin karena adanya kalsium dalam bentuk ion yang tidak bisa disintesis melalui proses metabolisme. Sehingga meskipun kadar air dalam jaringan tanaman bayam merah sudah hilang kalsium akan tetap berada di dalam jaringan tanaman. (Lakitan,
2010) kalsium juga merupakan ion yang berperan menjaga tekanan turgor, dan tekanan osmotik yang nantinya berfungsi untuk membuka dan menutunya stomata. Selain itu juga mungkin karena kadar air dalam bagian tanaman perlakuan 15 dan $20 \%$ tidak jauh berbeda sehingga tidak berpengaruh juga untuk berat segar dan berat kering tanaman.

\section{KESIMPULAN}

MOL rebung bambu surat berpengaruh terhadap pertumbuhan bayam merah. Pemberian MOL rebung bambu yang memberikan hasil terbaik adalah $\mathrm{P}_{2}$ dengan tinggi, berat segar, dan berat kering secara berurutan $30,34 \mathrm{~cm} ; 15,40 \mathrm{~g}$; $1,04 \mathrm{~g}$, atau 200,$66 ; 292,22 ; 297,14 \%$ terhadap kontrol.

\section{DAFTAR PUSTAKA}

Andrianni, D. M., Setyaningsih, M., \& Susilo, S. (2017). Keanekaragaman dan Pola Penyebaran Insekta Permukaan Tanah di Resort Cisarua Taman Nasional Gunung Gede Pangrango Jawa Barat. Jurnal Bioeduscience, 1(1), 24. doi: 10.29405/bioeduscience/24-30111179

Anggoro, S dan Hardiyati, T. 2010. Fisiologi Tumbuhan. Jakarta : Universitas Terbuka.

Dalimartha, dan Andrian. 2013. Fakta Ilmiah Buah dan Sayur. Jakarta : Penebar Plus.

Dwijoseputro, D.1978. Pengantar Fisiologi Tumbuhan. Jakarta : PT. Gramedia Pustaka Utama.

Erwin, E. (2017). Inokulum Mikoriza Arbuskula sebagai Pupuk Hayati pada Tanaman Gandum (Triticum Aestivum L.). Jurnal Bioeduscience, 1(1), 38. doi: 10.29405/bioeduscience/3844111180

Heddy, Suwasono. 1986. Hormon Tumbuhan. Jakarta : Rajawali

Lakitan, Benyamin.2010. Dasar - Dasar Fisiologi Tumbuhan. Jakarta : Rajawali Pers.

Mulyono. 2014. Membuat MOL dan Kompos dari Sampah Rumah Tangga. Jakarta : PT. AgroMedia Pustaka.

Nurgana, Endi. 1985. Statistika Untuk Penelitian. Bandung : CV Permadi.

Nugroho, Agus. 2014. Meraup Untung Budidaya Rebung. Yogyakarta : Pustaka Baru Press. 
Purwasasmita, Mubiar dan Sutaryat, Alik. Padi Sri Organik Indonesia. Bandung : Penebar Swadaya.

Redaksi, Trubus. 2013. Kiat Tingkatkan Produksi Padi. Jakarta : PT. Niaga Swadaya

Samekto, Riyo. 2006. Pupuk Daun. Yogyakarta : PT. Citra Aji Parama.

Setiawan, Budi Susilo. 2010. Membuat Pupuk Kandang Secara Cepat. Bogor : Penebar Swadaya.

Sunarjono, Hendro. 2014. Bertanam 36 Jenis Sayuran. Jakarta : Penebar Swadaya.

Susilo, S., \& Suciati., R. (2016). Studies of Morphological and Secondary Metabolites Variaty of Mosses (Bryophyta) in Cibodas, West Java. International Journal of Advanced Research, 4(12), 1397-1402. doi: 10.21474/IJAR01/2536

Susilo, \& Setyaningsih, M. (2018). Analysis of genetic diversity and genome relationships of four eggplant species (Solanum melongena L) using RAPD markers. Series: Journal of Physics: Conf. Series, 948(012017), 1-6. doi: 10.1088/1742$6596 / 948 / 1 / 012017$ 